\title{
A geotechnical and GIS based method for evaluating risk exposition along coastal cliff environments: a case study of the chalk cliffs of southern England
}

\author{
A. Stavrou ${ }^{1}$, J. A. Lawrence ${ }^{2}$, R. N. Mortimore $^{2}$, and W. Murphy ${ }^{2}$ \\ ${ }^{1}$ National and Kapodistrian University of Athens, Faculty of Geology and Geoenvironment, Athens, 157 84, Greece \\ ${ }^{2}$ The University of Leeds, School of Earth and Environment, Leeds, LS2 9JT, UK
}

Received: 24 December 2010 - Revised: 4 October 2011 - Accepted: 13 October 2011 - Published: 9 November 2011

\begin{abstract}
The present work has established a methodology that allows the user to determine areas susceptible to shoreline recession and cliff instability. This methodology includes the development of a qualitative loss estimation system which utilizes geotechnical field mapping observations and shoreline retreat predictions to estimate the exposition of critical infrastructure to hazards posed by cliff collapse and retreat. The technique identifies hazardous areas along coastal cliff environments. The assessment was undertaken along the cliff section between Brighton Marina and Portobello, East Sussex, UK. The cliff line was divided into $22 \mathrm{sec}-$ tions according to the cliff's geology. Each of these sections was mapped and described with respect to the lithology and possible failures that could occur. Historical shoreline recession analysis was used for the prediction of future shoreline positions. The prediction of future shorelines was performed by using the Digital Shoreline Analysis System, extension of ESRI's ArcView 9.x. The analysis was based on historical maps and aerial photographs dating from 1873 to 2005. The long term average cliff recession rates clearly show that cliff retreat has declined through time due to the presence of coast protection and cliff stability measures. Although these measures have delayed cliff recession to a great extent, they have not eliminated it.
\end{abstract}

\section{Introduction}

Coastal cliff instability is an increasing problem for many local authorities and government agencies throughout the world. Much of the chalk cliff coast line of northwest Europe and particularly southeast England suffers from sud-

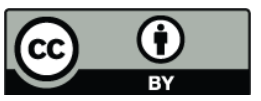

Correspondence to: A. Stavrou (anstavrou@hotmail.com) den catastrophic cliff failure mitigated against using various methods: (i) infrastructure protecting the cliffs, (ii) instrumentation monitoring the cliffs (Senfaute et al., 2009), (iii) hazard or risk assessments, (iv) visual monitoring and measurement or managed retreat (Mortimore et al., 2004; Lawrence et al., 2007).

The section between Brighton Marina (Black Rock) and Portobello (Fig. 1) in East Sussex, UK, is representative of large sections of chalk cliff where failures have occurred in the past. The most significant impact of coastal landsliding is the shoreline retreat, which influences residents' safety and critical infrastructure. In other words, cliff instability has a great socio-economic impact on the adjacent densely populated coastal area. In particular, the study area is characterised by a range of hazards which threaten:

1. the security of pedestrians and cyclists that are using the undercliff walk;

2. the footpath along a narrow strip of land located next to the cliff top;

3. the coastal road (A259) which run parallel to the cliff top and is the main trunk road;

4. the services found just behind the sea-cliffs.

Along this section the cliff is characterized by the Newhaven Chalk Formation, Palaeogene sediments and Quaternary deposits. The most common cliff failures are large planar, block and wedge failures as well as small debris falls that often occur in weathered zones. The ultimate cause involved in cliff instability is the action of gravity (Lee and Clark, 2002). Cliff failures are predominately linked with the lithology, the structure of the chalk formation as well as the weather conditions and the wave action (Mortimore et al., 2004). Specifically, they are principally controlled by steeply inclined conjugate shear joints of the chalk, which result in

Published by Copernicus Publications on behalf of the European Geosciences Union. 

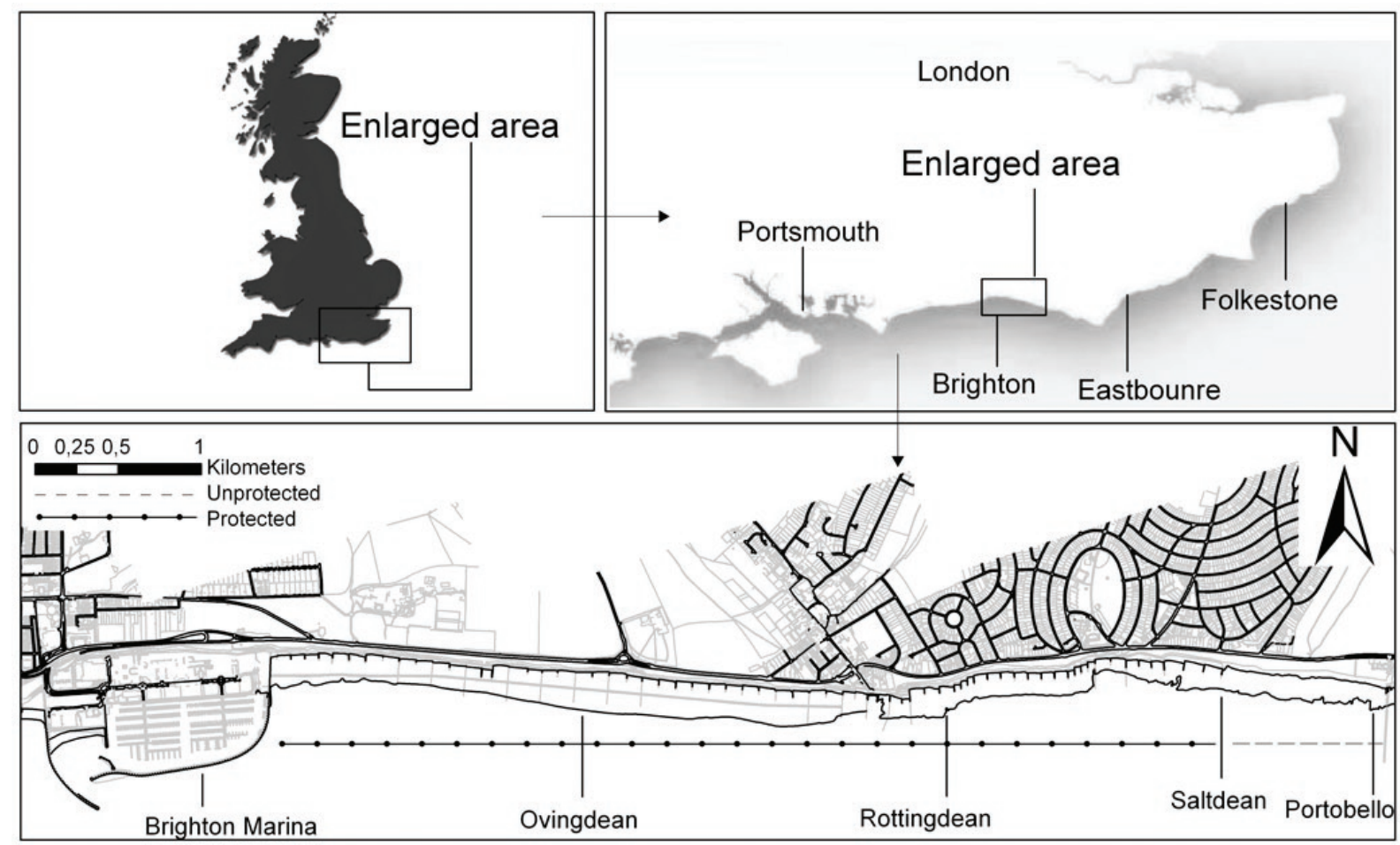

Fig. 1. Location of the study area.

small-scale and large-scale failure events, especially when they daylight in the cliff face at critical angles greater than the friction angle. Other factors that seem to be responsible for coastal landsliding are the alteration of freeze-thaw events that causes the enlargement of cracks and joints, as well as the disintegration of the material (Bell, 2007). In addition, climate changes seem to affect significantly the sea levels as well as the frequency and magnitude of storms. It is strongly believed that these extreme climate changes will gradually lead to a considerable shoreline retreat, especially for those sea-cliffs that are in comparably soft geological formations, such as the chalk found in the study area (Bray and Hooke, 1997).

Many cliff failures occurred during the wet winter of 2000-2001 highlighting once again that cliffs will always be susceptible to failures. Therefore, regular hazard-based inspections of the cliffs are necessary to ensure the safety of the public.

This paper presents the results of a qualitative risk exposition assessment undertaken by applying a methodology which is able to evaluate the risk of coastal chalk cliff instability by taking into account the hazards associated with geological conditions and geological processes identified from field mapping observations, the evolution of the shoreline and the consequences of socio-economic susceptibility (Baynes, 2010).
In order to describe the methodology applied in this study it is necessary firstly to clarify those terms and elements that contribute to the risk exposition assessment. As defined by the United Nations Development Programme (UNDP, 2004) risk is the process of defining the consequences or negative impact of a hazard (e.g. block failure) to public health and property. Because of the lack of data that could drive to a complete quantitative risk approach, in our specific assessment, the term "risk" is therefore used to describe an expertbased qualitative combination of spatial hazard indication and likely consequences excluding quantitative hazard and vulnerability assessments. In this work the term "hazard" simply describes the anticipated type, size and location of hazardous cliff movements without taking into account their temporal probability and frequency occurrence. Finally, consequences are the adverse influences of a hazard which affect the quality of human life or the environment (Lee and Clark, 2002).

\section{Study area}

The study area (Fig. 1) is located in East Sussex, UK and covers the extend chalk cliff section between Brighton Marina in the west to Saltdean in the east (OS Grid Reference: TQ 33739 03153-TQ 38713 02313). The site is approximately $6 \mathrm{~km}$ and can be divided into two main sections: the protected $(\sim 5.5 \mathrm{~km})$, which is managed by the Brighton 


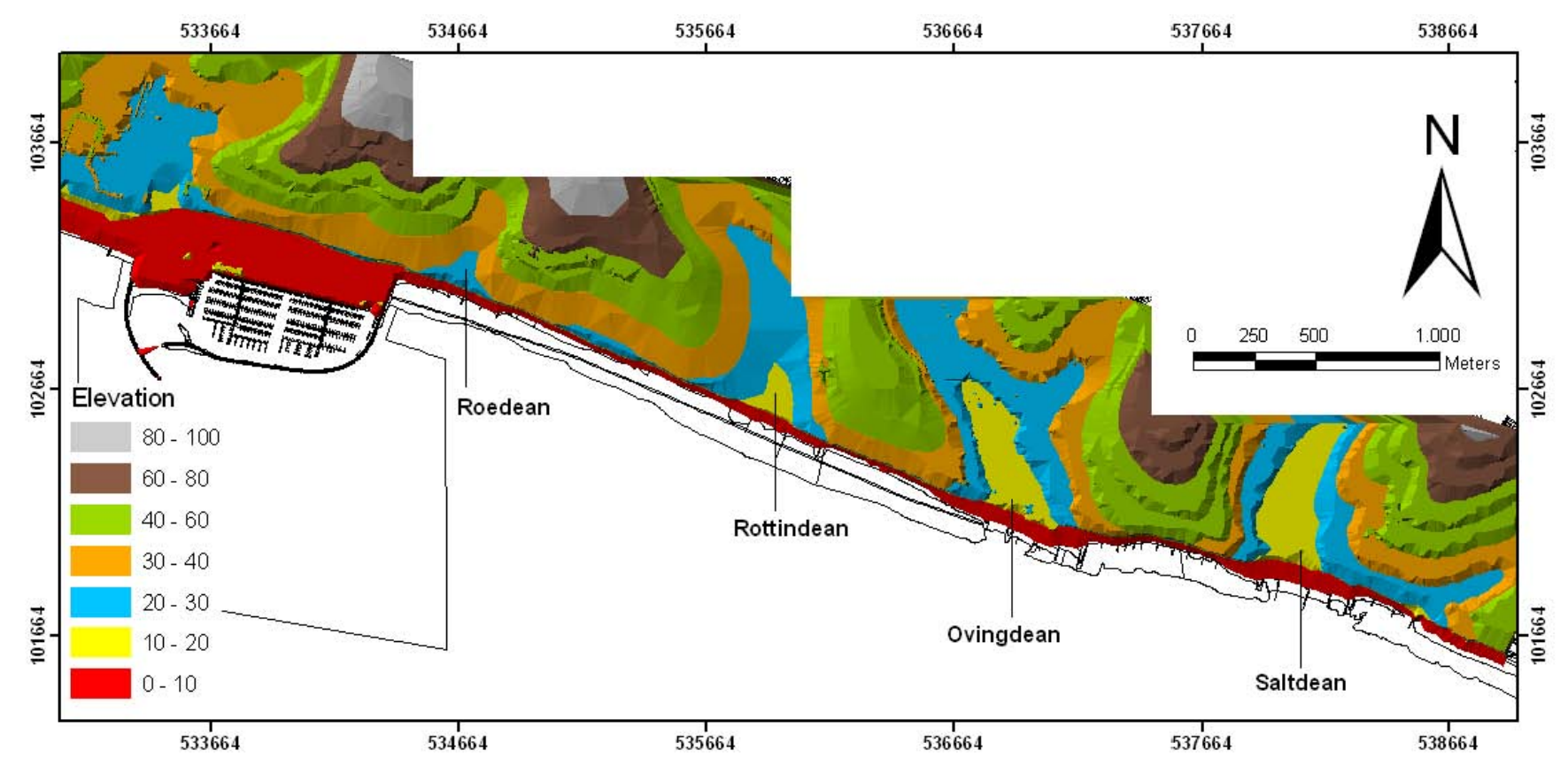

Fig. 2. Elevation map of the study area shows the impact of the dry valleys on the local morphology.

and Hove City Council (B\&HCC), and the unprotected area $(\sim 500 \mathrm{~m})$, which is managed by Lewes District Council. The access points to the undercliff walk are found at Saltdean, Rottingdean, Ovingdean, Roedean and Black Rock.

\section{Geology}

The coastal cliffs between Brighton Marina and Portobello are composed entirely by the Newhaven Chalk Formation (Mortimore, 1986; Bristow et al., 1997 and ratified by Rawson et al., 2001) that dips gently to the South (Fig. 3).

The Newhaven Chalk Formation was deposited during the Upper Cretaceous Epoch (100-65 million years (Ma). Generally, this Formation is pure and mainly composed of fine calcium carbonate coccolith debris (Mortimore et al., 2001). The Formation is characterised by firm white chalks with numerous marl seams and repeated layers of flints (Mortimore, 1983, 1986a, b). Typically this, chalk is fragmented by normal and reverse faults and steeply inclined $\left(60-70^{\circ}\right)$ conjugate shear joints that play a significant cliff failure mechanism (Mortimore et al., 2004). This fracture pattern reflects the regional tectonic stresses and pressures that have affected the chalk. The exposure and the structure of the Newhaven Chalk Formation are largely controlled by gentle tectonic folds. These are the Friars Bay Anticline and the Old Steine Anticline. These tectonic folds have an impact on the dip direction of the chalk and up to a point control the types and scales of cliff failures (Mortimore et al., 2004).

The drift geology is characterised by Palaeogene sediments and Quaternary deposits (Fig. 3). These formations are found in a series of dry valleys and at Black Rock, Brighton Marina where an ancient raised beach and overlying coombe deposits are exposed. Within the site four dry valleys have been developed east of Black Rock at Roedean, Ovingdean Rottingdean and Saltdean which have affected the topography of the study area (Fig. 2). The dry valleys consist of Head deposits and intersect the cliff line. The term Head describes unstratified deposits, such as hill-wash, valley-fill and slope deposits, which rest in the river valleys and on the coastal plain (Mortimore et al., 2004; BGS, 1988). The chalk is found to be more weathered and weakened in the flanks and the floors of the dry valleys. In these valleys the chalk has degraded in-situ as a result of freeze-thaw cycles in which large amount of fines have transported (Lawrence et al., 2007).

Chalk weathering varies along the height of the cliffs with the upper parts being more weathered and fragmented and the lower parts being more blocky. This has caused frost shattering due to numerous freeze-thaw cycles that have impacted the upper part of the cliff during the Quaternary period (Mortimore and Greensmith, 1997; Dornbusch et al., 2008).

\section{Hazard indication mapping}

Hazard indication mapping was carried out by walking along the cliff line between 21 June and 15 July 2010 . For the protected section, this was performed by walking along the promenade at the toe of the cliff. The small unprotected section east of Saltdean was covered by walking along the coast. The findings along this unprotected section are considered valuable as they display a more realistic nature of 


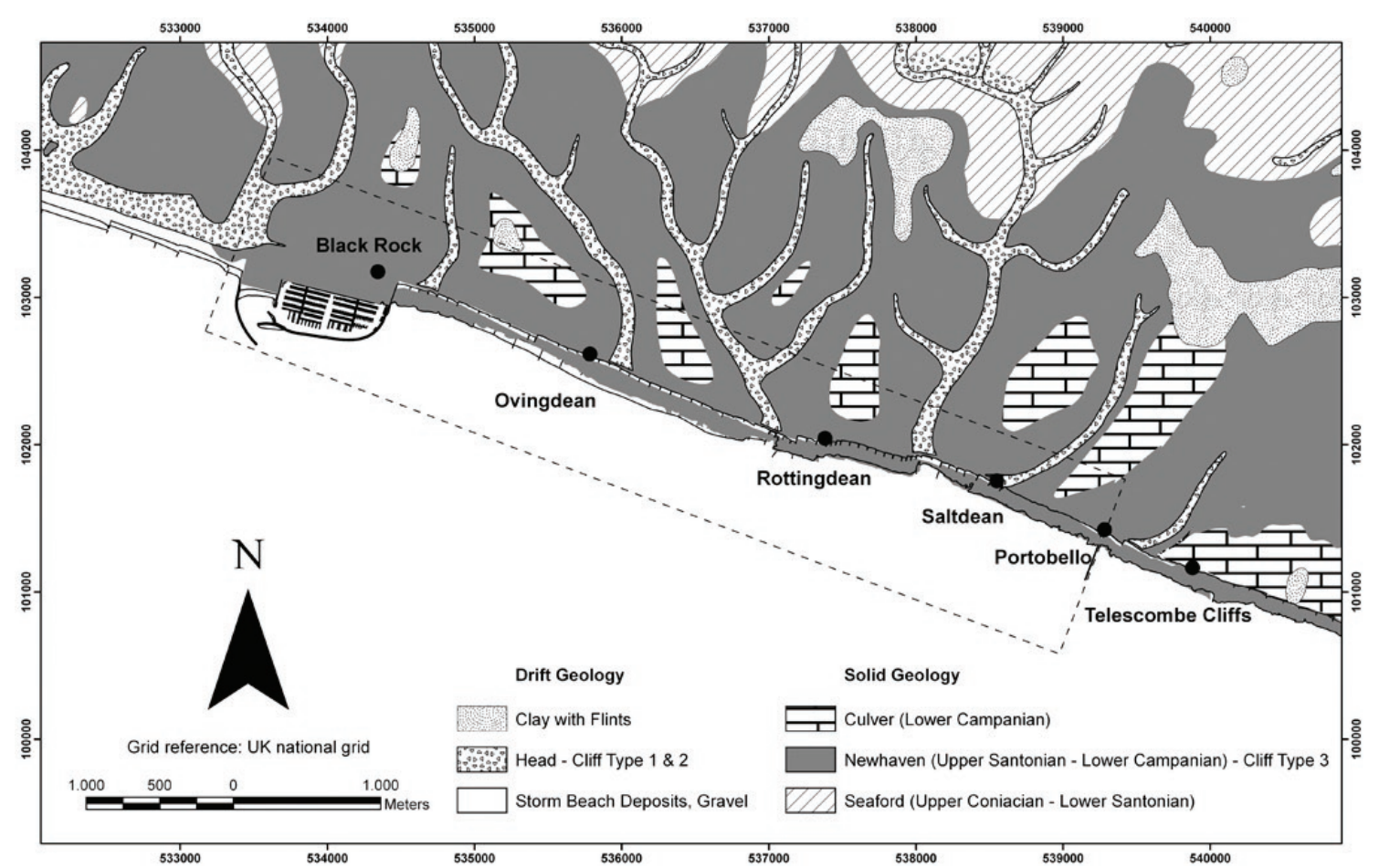

Fig. 3. Distribution of the solid and drift geology along the site.

cliff recession. A detailed walkover along the cliff top was conducted to examine the presence and evidence of the signs of cliff instability. Previous cliff risk assessments along this section, undertaken in 1999 and 2001 by High-Point Rendel formed the basis of field mapping. These reports assessed the hazard and risk considering the condition of the cliff and the relative risk present to the people and properties in the vicinity of the cliff face. One of the investigative tasks was to verify and update the findings of these reports by identifying the hazards along the coast.

Hazard indication mapping was based on a combination of two mapping techniques; the direct and the indirect mapping method (Hearn and Griffiths, 2001). The direct mapping method is based on the knowledge of previous failures and the indirect method on the knowledge of which type of material is more susceptible to failure than another. As identified by Parry and $\mathrm{Ng}$ (2010) the purpose of mapping is to (i) evaluate observations from aerial photography; (ii) to evaluate the initial and other hazard models; (iii) to record any additional evidence of hazards.

For mapping purposes the cliff line was divided into a series of discrete sections according to geological and morphological characteristics. Each of these sections belongs to a Cliff Type (Table 1). The term "cliff type" refers to areas that are characterised by similar features such as lithology, type and orientation of the discontinuities and styles of failures that can be observed in several non-adjacent sections. In total the site was divided into 22 sections (Fig. 4).
Table 1. Cliff Type Classification (High-Point Rendel, 1999, 2001, unpublished).

\begin{tabular}{llll}
\hline $\begin{array}{l}\text { Cliff } \\
\text { Type }\end{array}$ & $\begin{array}{l}\text { Sub- } \\
\text { Type }\end{array}$ & $\begin{array}{l}\text { Geological Material } \\
\text { Exposed in the Cliff }\end{array}$ & $\begin{array}{l}\text { Brief } \\
\text { Description }\end{array}$ \\
\hline 1 & - & Raised Beach Deposits & $\begin{array}{l}\text { Raised Beach and Head de- } \\
\text { posits present over entire cliff } \\
\text { profile. Weathered, structure- } \\
\text { less chalk present adjacent of } \\
\text { cliff }\end{array}$ \\
\hline 2 & - & $\begin{array}{l}\text { Dry Valley Deposits, } \\
\text { Exposure of underlying } \\
\text { Chalk may be present }\end{array}$ & $\begin{array}{l}\text { Dry valley deposits present over } \\
\text { entire cliff height, or weathered, } \\
\text { unstructured chalk exposed in } \\
\text { cliff bellow dry valley deposits }\end{array}$ \\
\hline 3 & $3 \mathrm{~A}$ & Chalk & $\begin{array}{l}\text { Thickly bedded, joints gener- } \\
\text { ally widely spaced, generally } \\
\text { slightly weathered }\end{array}$ \\
& & Chalk & $\begin{array}{l}\text { Generally slightly weathered } \\
\text { with high state of fracture com- } \\
\text { pared with Cliff Type 3A }\end{array}$ \\
\hline 3B & &
\end{tabular}

Hazard indication mapping was conducted by geotechnical observations. This technique depends on the field engineers experience and therefore it can never be considered as a fool proof predictive method. 

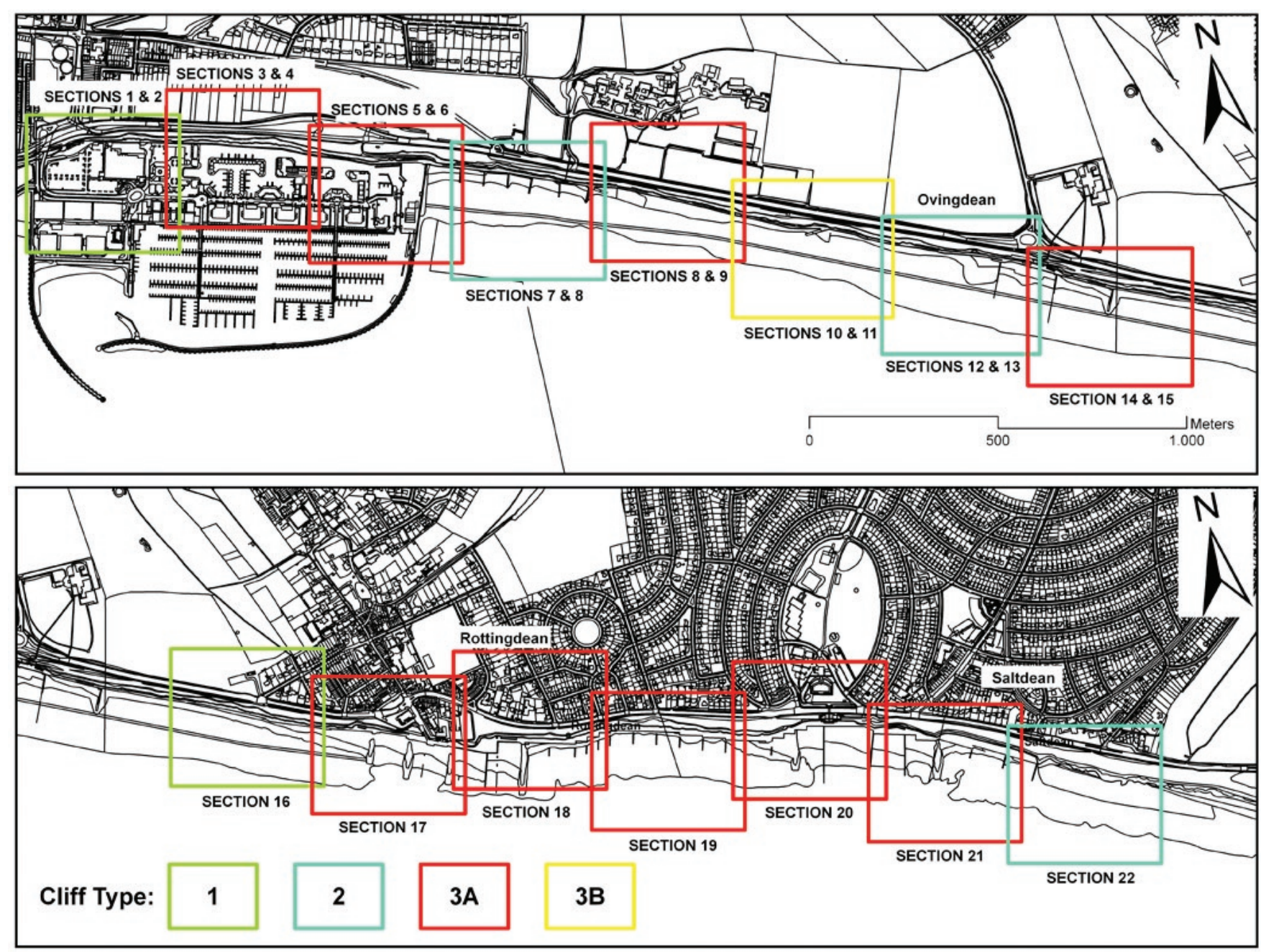

Fig. 4. Key plan showing the location of Sections 1-22.

The key observations identified, recorded and measured during the site visit include the following:

- proximity of the costal road (A259) to the cliff edge;

- narrow sections of the undercliff walk;

- wave attack undermining the unprotected cliff sections;

- overhanging vegetation, weathered chalk or dry valleys deposits;

- isolated block failures undermining the lower cliff;

- isolated recent chalk and flint nodules falls (Fig. 5);

- dissolution of chalk;

- failure scars;

- the variety of geological materials leading to different types of failures;
- historical documents cataloguing past major instability, most recently documented in 2001 along the protected section of cliff;

- measurement and characterisation of conjugate set of joints which lead to large scale wedge and block failures;

- the coastal defence measures along the site have reduced the rate of shoreline recession compared to the unprotected section, but they have not eliminated it.

Figure 5 illustrates typical examples of coastal cliff failures across the site. Generally the observed cliff conditions are mostly related with lithology and the orientation and the style of fractures; the depth of weathering and the amount of drift sediments that occupy the valleys (Lawrence et al., 2007). Each of these hazards has different influence to human life and to the environment and as a result they produce different harmful and damage effects. 

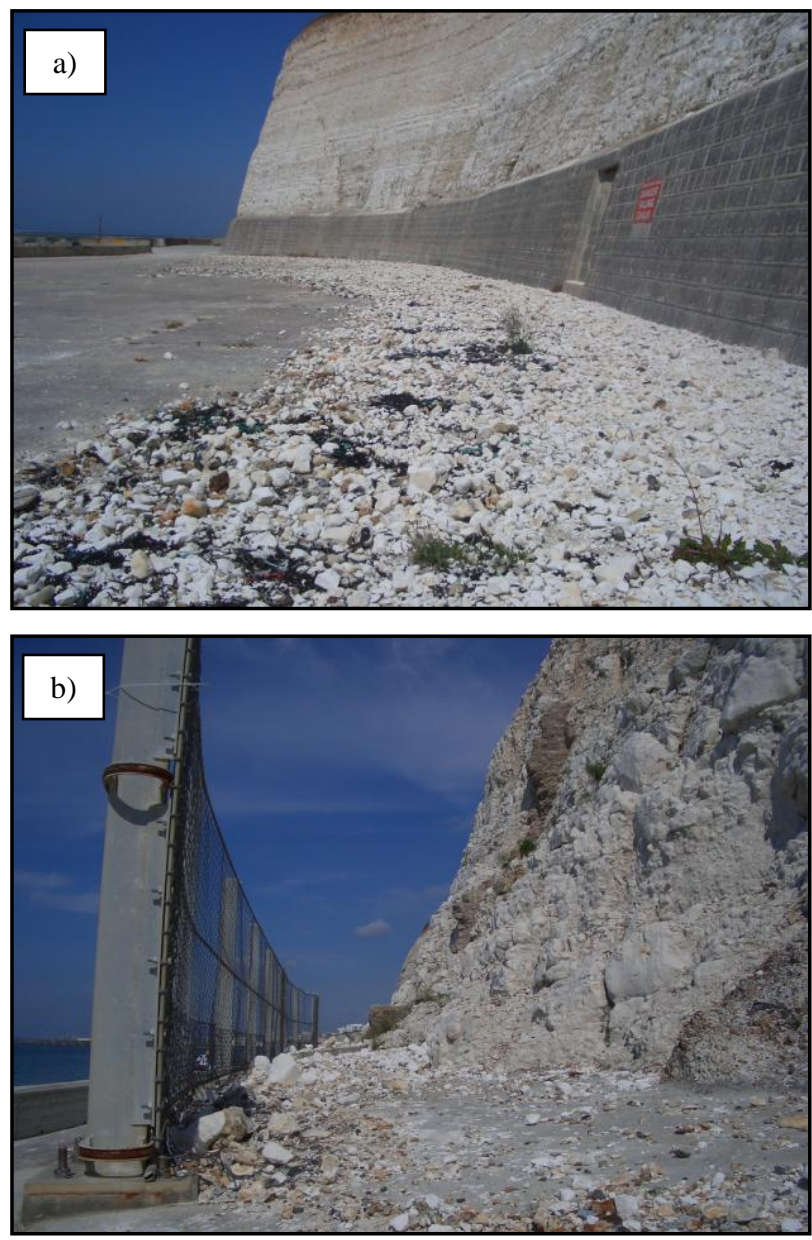

Fig. 5. (a and b) Examples of isolated recent chalk and flint nodules falls.

\section{Shoreline recession analysis}

Although the factors that influence the shoreline recession are well known, we still have difficulties to input this knowledge into mathematical models in order to estimate shoreline changes over long periods of time. The main reason for this is that the shoreline changes depend on various factors including geology, topography, climate variability and weather conditions (Benjamin et al., 2008; Dornbusch et al., 2008). All these factors make the estimation of average retreat rates and average cliff loss difficult to determine.

The current study is supported by a historical shoreline retreat analysis provided by B\&HCC. Historical study of shoreline retreat is a very useful tool for coastal management not only because it provides information for the shoreline evolution but also because it provides evidence for the performance and behaviour of protection measures through the course of time so as to organize future coastal defence strategies (Halcrow Group Limited, 2007). The analysis was based on Historical Ordnance Survey maps and aerial photographs.
The analysis was undertaken by using the Digital Shoreline Analysis System (DSAS) 4.0 (Himmelstoss, 2009), an extension that was developed by the United State Geological Survey and co-operate with the Environmental Systems Research Institute (ESRI) Geographic Information System (ArcGIS 9x) software. The main application of this extension is the estimation of the average rate of shoreline retreat in comparison with the historical shoreline positions. DSAS is also able to compute future shoreline raster data for both short and long time periods (Himmelstoss, 2009). In the present case, the reason for using the calculated rates of cliff line retreat was the prediction of the future shoreline positions, as well as the detection of areas of high shoreline recession. This method that is able to extrapolate data from historical maps and aerial photos and to use them to estimate the location of future shorelines is known as Historical Trend Extrapolation (Benjamin et al., 2008, Hooke and Kain, 1982). This method is considered as a valuable tool for future predictions and it has been widely applied by researchers and engineers of coastal environments (Crowell et al., 1997; Crowell and Leatherman, 1999). The main limitation of this method is that the output data represents average values and therefore it is unable to record specific events such as the removal of a single block.

Alterations of chalk cliff retreat rates were calculated over a period of $132 \mathrm{yr}$ (from 1873 to 2005) for the $6 \mathrm{~km}$ cliff section using the linear regression method. According to Morton et al. (2004) this technique has been proven to be the most suitable statistical method for calculating recession rates using historic data. Eight different historical shorelines, dated from 1873, 1897, 1911, 1931, 1952, 1970, 1980 and 2005, were digitized from historical Ordnance Survey maps and recent large scale aerial photographs. The construction of these polylines and the statistical results of the DSAS depend on the reliability and the accuracy of the available sources. It should be noted, that generally is impossible to gain objective accuracy from the shorelines shown on historical maps (Dornbusch et al., 2008). According to Dornbusch et al. (2006) the positional accuracy of the historic maps has been found to contain an error of $\pm 3 \mathrm{~m}$. On the other hand, air photographs provide a cliff line with a positional accuracy of $\pm 0.3 \mathrm{~m}$. Cliff line recession rates were calculated every $20 \mathrm{~m}$ along the shoreline. Afterwards, the computed recession rates were grouped together according to the sections shown in Fig. 4. Table 2 illustrates the average rates of recession and the average distances that covered for different time periods. A visual example of shoreline changes along the site is shown in Fig. 6.

According to these results, it is evident that there is a decline in cliff retreat through time especially for the period between 1952 and 2005. The decline in cliff retreat was linked to the development of coastal protection measures along the site. 


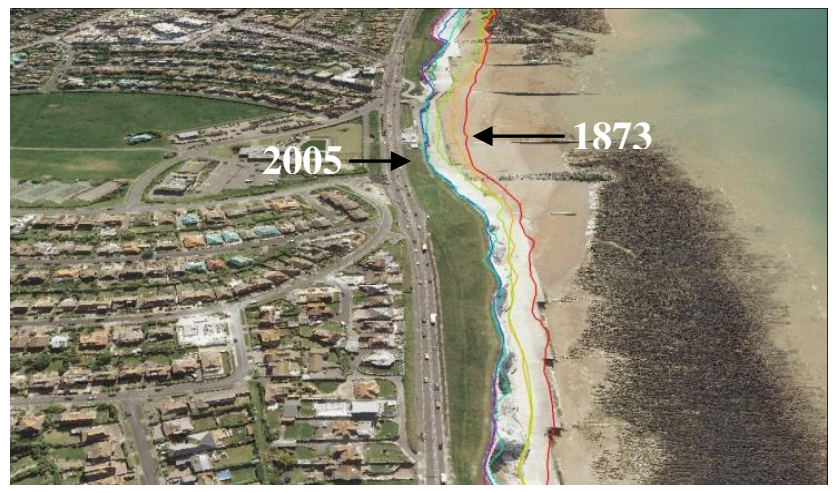

Fig. 6. Visual example of shoreline changes

Table 2. Shoreline retreat rates and average covered distances for different time periods.

\begin{tabular}{lrrrr}
\hline $\begin{array}{l}\text { Time } \\
\text { Period }\end{array}$ & $\begin{array}{r}\text { Number } \\
\text { of Years }\end{array}$ & $\begin{array}{r}\text { Av. Rate of } \\
\text { Retreat } \\
\left(\mathrm{m} \mathrm{yr}^{-1}\right)\end{array}$ & $\begin{array}{r}\text { Av. Covered } \\
\text { Distance } \\
(\mathrm{m})\end{array}$ & $\begin{array}{r}\text { Standard } \\
\text { Deviation }\end{array}$ \\
\hline 1873 & 0 & 0.00 & 0 & 0 \\
$1873-1897$ & 24 & 0.24 & 5.9 & 0.19 \\
$1897-1911$ & 14 & 0.64 & 9.0 & 0.43 \\
$1911-1931$ & 20 & 0.38 & 7.7 & 0.36 \\
$1931-1952$ & 21 & 0.11 & 2.2 & 0.13 \\
$1952-1970$ & 18 & 0.03 & 0.5 & 0.15 \\
$1970-1980$ & 10 & 0.01 & 0.1 & 0.08 \\
$1980-2005$ & 25 & 0.05 & 1.2 & 0.09 \\
\hline $1873-2005$ & 132 & 0.22 & 26.4 & 0.09 \\
\hline SD & - & 0.09 & 3.65 & \\
\hline
\end{tabular}

Since the 1930's the section that is managed by B\&HCC has been protected by various protection measures, including: groynes at regular intervals; a concrete seawall at the base of the cliff; a promenade above the seawall and a $2 \mathrm{~m}$ high splash wall at the back of the promenade. Moreover, trimming of the cliff face to an average $70^{\circ}$ inclination was performed to enhance the stability of the chalk. In the 1980's further coast protection actions were undertaken so as to enhance the foregoing defence measures (Fig. 7) (High-Point Rendel, 1999, unpublished; Mortimore et al., 2006). In addition to the existing protection measures, a cliff stabilization programme began after the wet winters of 2000/01, which were characterised by a series of catastrophic failures, so as to enhance the safety of the public by reducing the risk of cliff failure. These measures included: localised rock bolting; sub-horizontal rock catch nets at mid cliff; vertical rock catch fences; shingle beds to catch smaller falls of chalk and flint and cliff trimming to remove unstable blocks of chalk. (Mortimore et al., 2006; High-Point Rendel, 1999, unpublished).

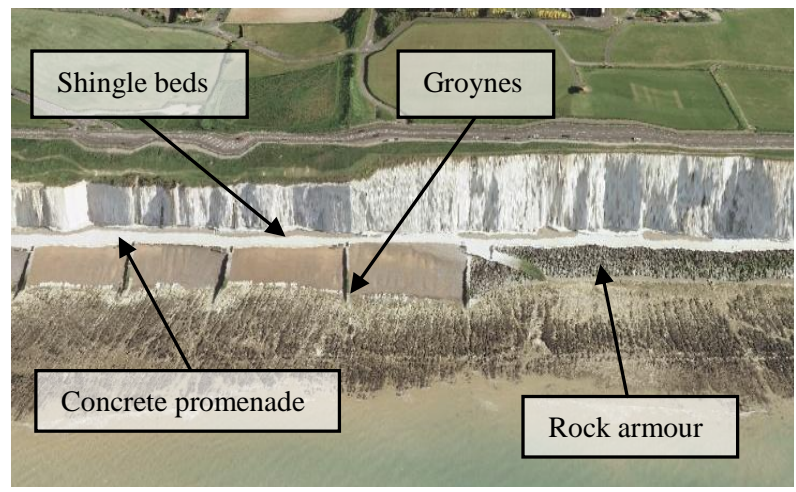

Fig. 7. Examples of protection measures along the coast.

Table 3. Average retreat rates for different time periods.

\begin{tabular}{lrrr}
\hline $\begin{array}{l}\text { Time } \\
\text { Period }\end{array}$ & $\begin{array}{r}\text { Av. Rate of } \\
\text { Retreat } \\
\left(\mathrm{m} \mathrm{yr}^{-1}\right)\end{array}$ & SD & $\begin{array}{r}\text { Average } \\
\text { Covered } \\
\text { Distance }(\mathrm{m})\end{array}$ \\
\hline $1873-1931$ & 0.42 & 0.17 & 22.50 \\
$1931-1980$ & 0.20 & 0.22 & 10.40 \\
$1980-2005$ & 0.04 & 0.09 & 1.100 \\
$1873-2005$ & 0.32 & 0.10 & 49.00 \\
\hline
\end{tabular}

Note: 1873 to 2005 period refers to the section that belongs to Lewes District Council. SD: standard deviation.

In order to examine the impact of the engineering structures on the shoreline recession, the cliff retreat rates were re-calculated separately firstly for the area that is managed by B\&HCC (protected area) and secondly for the section east of Saltdean (unprotected area). Specifically, for the protected section the calculations were undertaken by taking account of the dates of construction and maintenance of the protection measures. For this purpose, the 132 time year period was divided into three time periods (Table 3 ).

As it would be expected the presence of coast protection measures has influenced the coastal processes. The emplacement of protection and stability measures has successfully protected the cliff section from factors causing chalk cliff instability such as wave attack and fluctuations of sea levels. In general, coast protection has reduced the rates of marine erosion. For the unprotected cliffs east of Saltdean the long-term average rate of recession was determined to be $0.32 \mathrm{~m} \mathrm{yr}^{-1}$. The fact that the average rate of cliff recession was similar to the value calculated for the protected section for the period between the years 1873 and 1931 revealed that cliff retreat rates for the unprotected section have remained approximately the same for the last $130 \mathrm{yr}$. Consequently, on the cliff top there is a hazardous narrow strip of land between the cliff edge and the coast road (A259) which in some points has only $40 \mathrm{~m}$ width. 


\section{Future shoreline prediction}

Because the nature of the coastline retreat is a very complex process, the prediction of future shoreline recession includes many uncertain variables. These are the future weather conditions, the behavior of sea defence structures over the time and the rising sea level (Halcrow Group Limited, 2007). Coastal evolution is also difficult to predict due to the spatial and temporal pattern of shoreline change (Barter et al., 2003). It has also been proven that erosion is often episodic and only one failure event can cause several meters retreat of the cliff line (Mortimore et al., 2004; Dornbusch et al., 2008; Lee and Clark, 2002; Dong and Guzzetti 2005).

A prediction of the shoreline for the next $20 \mathrm{yr}$ was chosen, because this date is close to the present and therefore the result of this calculation is useful for coastal management and land-use planning. The methodology that was used accounts the calculated average annual recession for a specific time period to predict the future shoreline position (Leatherman, 1990; Crowell et al., 1997).

The time period that was chosen for the protected area is the one between 1980 and 2005 because this period represents the most recent available data and because during this period the behavior of the geological formations and the rate of cliff retreat have mainly affected by the presence of the current engineering structures. On the other hand the prediction of the unprotected section was based on the period between 1873 and 2005 as cliff recession was proven that remains constant through the passing of time. The method estimates future cliff positions, by multiplying the average recession rates with the time period $(T)$. In order to consider the variability of the values through the passing of the time, the standard deviation of the average rates was taken into account (Lee and Clark, 2002). Thus, the prediction of future recession rates can be expressed as follows:

Recession by year $A=$ (Average rate + Standard Deviation) $\times T$ years (Lee and Clark, 2002)

The factor $T$ is 25 which represents the time period between the most recent digitized shoreline (2005) and 2030.

Because cliff's lithology is a major factor that is related with cliff failures in East Sussex (Mortimore et al., 2004) and because the hazard mapping was performed section by section, it was decided for the shoreline prediction to be carried out in a similar way so as to create a link between shoreline analysis and field mapping. In order to testify that the spatial variability of cliff's lithology influences the shoreline recession, erosion rates were calculated for each section and grouped with respect to the cliff types. Table 4 proves that erosion is a process which reflects the variability of the geology along the site and therefore the estimation of future shoreline with respect to cliff's lithology is more realistic. Future shoreline recession rates cannot be assumed that they will remain constant into the future (Lakhan, 2005).
Table 4. Average retreat rates and average distances for different time periods, with respect to the Cliff's Lithology.

\begin{tabular}{lcrrrrr}
\hline & Cliff Type & 1 & 2 & $3 \mathrm{~A}$ & $3 \mathrm{~B}$ & \\
\hline \multirow{6}{*}{$1873-1931$} & 0.30 & 0.53 & 0.40 & 0.10 & A.R. \\
& & 17.3 & 30.76 & 23.11 & 6.07 & A.D. \\
& \multirow{2}{*}{$1931-1980$} & 0.08 & 0.15 & 0.09 & 0.04 & A.R. \\
& & 3.79 & 7.42 & 4.64 & 2.18 & A.D. \\
& $1980-2005$ & 0.01 & 0.02 & 0.01 & 0.06 & A.R. \\
& & 0.13 & 0.42 & 0.25 & 1.41 & A.D. \\
& $1873-2005$ & - & 0.49 & 0.32 & - & A.R. \\
& & - & 64.6 & 42.5 & - & A.D. \\
\hline
\end{tabular}

Note: 1873 to 2005 period refers to the section that belongs to Lewes District Council. A.R.: Average Rate of retreat $\left(\mathrm{m} \mathrm{yr}^{-1}\right)$, A.D: Average Covered Distance (m)

A changing climate and particularly an accelerated sea-level rise is believed to impact cliff retreat rates (IPCC, 2007) with an expectation that shoreline retreat rate will, generally accelerate in the future, leading to future instability issues (Appeaning Addo et al., 2008; Bray and Hooke, 1997). According to CCIRG (1996) the mean sea level is expected to increase up to $19 \mathrm{~cm}$ over the next $20 \mathrm{yr}$. As an attempt to detect possible impacts of future weather conditions and large failure events, the historical average recession rates where modified by a simple approach that was introduced by Moore et al. (2003). This method considers the influence of climate change and failure events simply by multiplying the calculated historical annual recession rate by a given percentage which is defined by the user. For this case the future shoreline recession rate was predicted by increasing the historical recession rate by $50 \%$. This value was chosen because, as Table 2 demonstrates, between the periods 1952-1980 and 1980-2005 there is an increase at cliff retreat approximately $50 \%$. Hence, it was assumed that this acceleration will continue for the period 2005-2030. It should be noted that the prediction assumes that the protection measures will remain in place over the time and they will have the same beneficial impact to the shoreline erosion rates. The future shoreline positions calculated for each section in conjunction with field mapping observations and other sources were used to perform the risk exposition assessment of the study area. Figure 8 illustrates two visual representations of future shoreline positions for both protected and unprotected coastlines as they were calculated with the aid of the DSAS extension.

\section{Risk exposition assessment}

Since the coastline of the site represents a dynamic environment, the chalk cliffs will always be susceptible to failures and the shoreline will continue to retreat inland as the cliff recession is a natural process which will never terminate, even with the presence of engineering structures such as seawalls and groynes (Dornbusch et al., 2008). Therefore, 

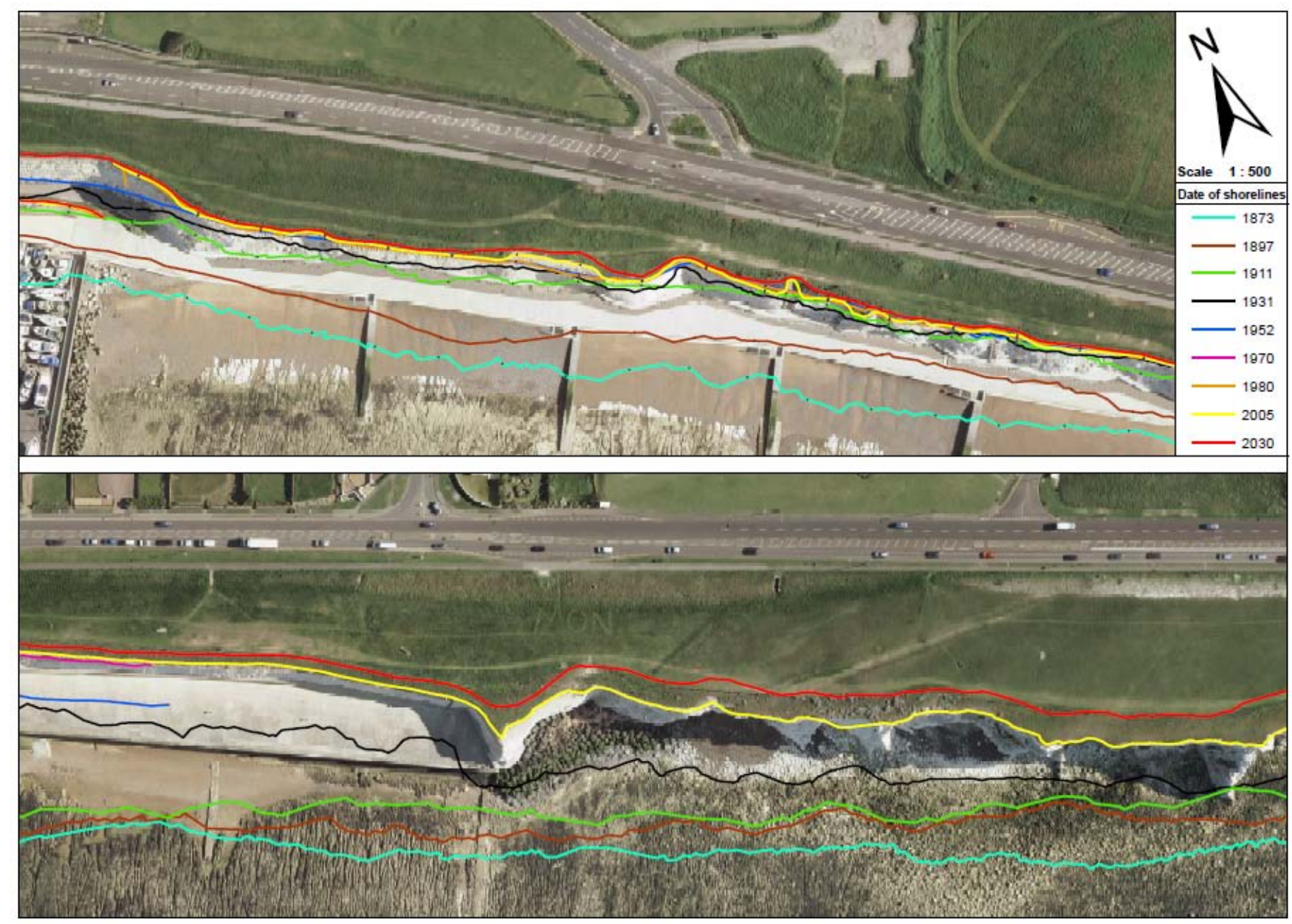

Fig. 8. Visual representations of future shoreline positions.

the hydro-dynamic regime along the coastal cliff environment will continue to change as will our response, this means the impact on human life is not just spatially but also temporally variable requiring continuing and contingent risk assessments which this model allows for.

The assessment was carried out by sub-dividing the coastal environment into sections based upon characteristics, different geological materials, hazards and shoreline recession rates (Mortimore et al., 2006; Lee and Clark, 2002). Consequently, different sections present different types and levels of risk. At this point it should be reminded that in the present assessment the term "risk" describes a qualitative compound of spatial hazard indication and likely consequences of exposed vulnerable objects to hazards posed by cliff collapse and retreat. However, the term does not include quantitative hazard and vulnerability assessments.

The presence of hazards was identified during the field mapping, the historical shoreline recession analysis and the literature review. The categories identified for the hazard element of the risk exposition assessment are shown in the following list and Table 5:
- small cliff failure/erosion involving detachment and transportation of surface material from the cliff face or the cliff top; isolated cobbles or individual small rocks (chalk or flint nodules); overhanging vegetation and Quaternary deposits;

- moderate failure and occasional small falling blocks of one or several blocks, often involving weathered material;

- substantial failure and occasional large falling blocks; failures involves numerous blocks and often large block failures;

- large failure and rock fall; planar failures; wedge failures; concrete structure collapses;

- major failure involving failure over the majority the cliff face, earthflows.

Before conducting the assessment of the area, it is necessary to underline the vulnerable elements at risk in order to understand the consequences of these hazards on them (Defra, 2002). These are: car drivers, pedestrians and cyclists 
using the coast road; the narrow land on cliff top; the coast protection structures; the coast road (A259) and pedestrians, cyclists and livestock using (i) the narrow path in the top of the cliff; (ii) the undercliff walk and (iii) the access paths to the promenade.

Considering and combining all possible factors, a loss estimation system was developed which is based on the classification:

1. of hazards that could be identified throughout the cliff system involving failures of specific size and type;

2. of hazards that would be responsible for the predicted shoreline retreat for the year 2030;

3. of the location of a hazard occurrence in conjunction with the likely consequences;

4. of the possible consequences to the human life and the environment, in general.

In these classifications (Table 5), each hazard and shoreline retreat value is represented as a number between the range 1 and 5, which reflects particular consequences to the public, property and environment. Taking into account each section's hazards, shoreline retreat, and consequence as previously described five risk classes (Table 6) from I (Least risk) to $\mathrm{V}$ (Highest risk) were defined. The flow net shown in Fig. 9 demonstrates the procedure followed for each section so as to reach the risk value for each section of the coast.

The final risk number is computed as follow:

Risk $\left(R_{N}\right)=$ Hazard score $(H) \times$

Shoreline retreat value score $(S) \times$ Consequence score $(C)$ or $R_{N}=H x S x C$

\section{Results}

The application of the described method has led to the production of a "risk zonation plan" (Fig. 10). This map was created by combining the risk value calculated for each of the 22 sections separately. The results show that between Brighton Marina and Portobello approximately $50 \%$ of the cliff line represents a high risk, emphasizing the useful spatial aspect of the applied methodology. For these areas, potentials failures were recognized in the field and high shoreline retreat was predicted with the use of the DSAS, extension of GIS. Particularly, all sections east of Rottingdean (Fig. 1) were found to represent a very high risk and should be considered areas of high priority in terms of remedial actions. Along these sections (19 to 22, Fig. 4), conjugate fracture pattern, developing overhangs and fragments of chalk and flint were observed in the field. Furthermore, it should be noted that this is the area with the most recorded major old

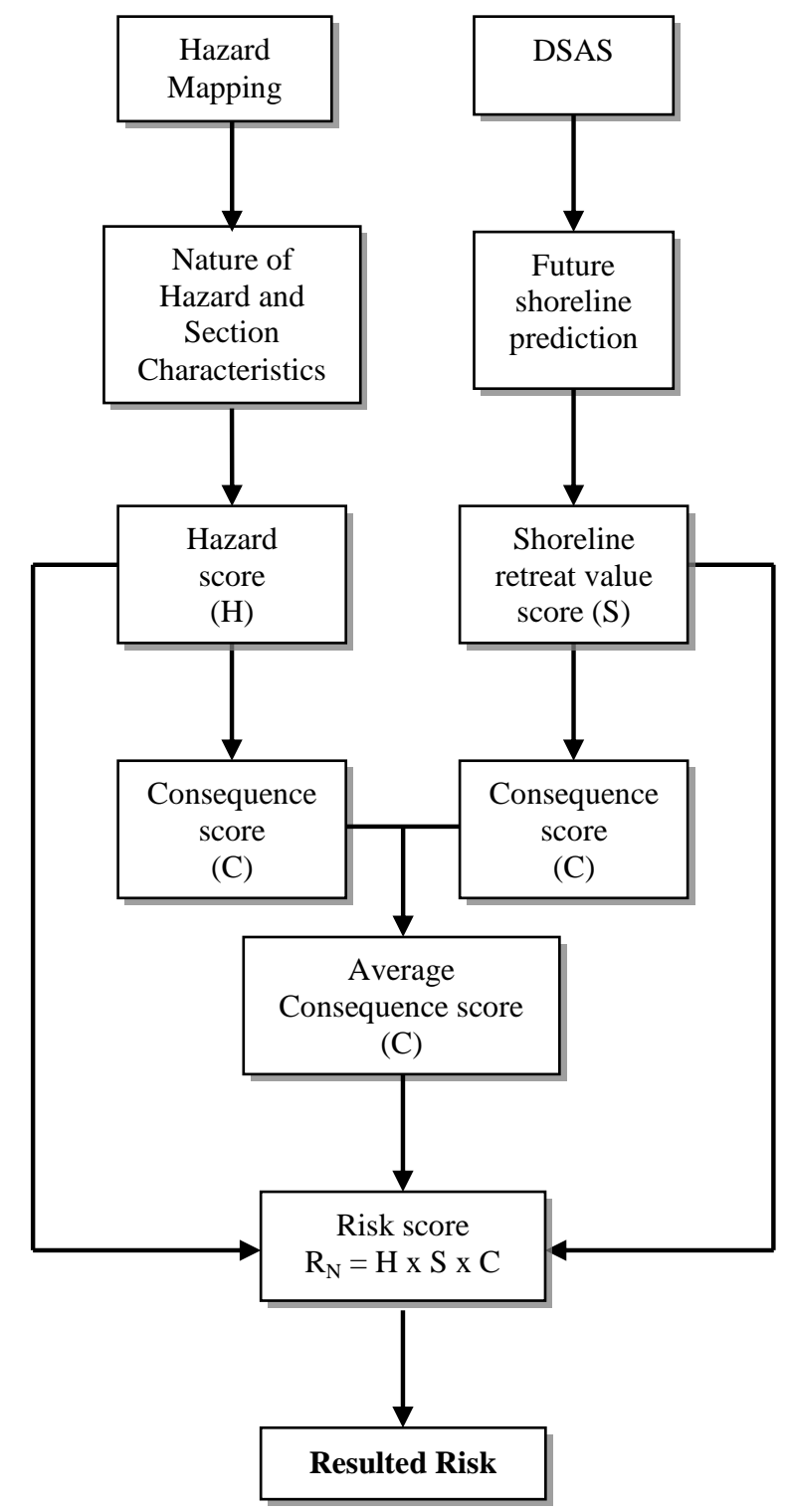

Fig. 9. The procedure of Risk estimation

failures. This leads to the conclusion that the style and frequency of joints and the general rock mass character of the Newhaven Formation enhances the presence of major failures along this section. Especially for Saltdean, Lawrence et al. (2007) found that the fracture system is able to trigger major wedge and planar failures.

For the unprotected area east of Saltdean (section 22) the high exposition to possible risk is related to the high rates of cliff retreat and the observed failures. Considering these elements, the method reaches the conclusion that there is a possibility of a major failure along this section, which may impact the coastal road (A259) which runs close to the cliff's edge. 
Table 5. Hazard and shoreline retreat value classifications.

\begin{tabular}{|c|c|c|c|}
\hline $\mathrm{Nr}$ & $\begin{array}{l}\text { Hazard } \\
(H)\end{array}$ & $\begin{array}{l}\text { Shoreline } \\
\text { value }(S)\end{array}$ & $\begin{array}{l}\text { Consequence } \\
(C)\end{array}$ \\
\hline 1 & Small cliff failure/erosion & $0-0.25$ & Little or no effect \\
\hline 2 & $\begin{array}{l}\text { Moderate Failure and occasional small } \\
\text { falling blocks }\end{array}$ & $0.25-0.50$ & $\begin{array}{l}\text { Small or minor effect to human and } \\
\text { property or environment }\end{array}$ \\
\hline 3 & $\begin{array}{l}\text { Substantial failure and occasional large } \\
\text { falling blocks }\end{array}$ & $0.50-1$ & $\begin{array}{l}\text { Major effect to human and property or } \\
\text { environment }\end{array}$ \\
\hline 4 & Large failure and rock fall & $1-3$ & Loss of life and property \\
\hline 5 & Major failure & $>3$ & Loss of life and property \\
\hline
\end{tabular}

The shoreline retreat value express the calculated distance between the 2005 and 2030 shorelines. Part of this table is based on a similar one developed by Boggett et al., 2000 .

Table 6. Risk classes.

\begin{tabular}{lll}
\hline Risk score $\mathrm{R}_{N}$ & Risk Classes & \\
\hline$>70:$ & Very High Risk & V \\
$50-70:$ & High risk & IV \\
30-50: & Medium Risk & III \\
10-30: & Low Risk & II \\
$0-10:$ & Very Low Risk & I \\
\hline
\end{tabular}

As it is shown in the risk zonation plan (Fig. 10), the other sections that represent high and very high risk rise out of the dry valleys (Saltdean-Ovingdean-Roedean/Black Rock). This is because these sections are characterised with population concentration, as they are used for access paths to the beach, and therefore even small failures can have major consequences. These sites consist of highly weathered chalk and Palaeogene deposits and therefore small cliff failures and small falling blocks are common and stochastic in nature. The shoreline recession analysis shows that these areas have displayed high retreat rates in the past and therefore, considering the nature of the material, this process will continue to occur in the future. The volume of material involved in failures has found to be far less because of the weathered nature of the formation and because the cliffs are not as high (Lawrence et al., 2007). Therefore, fragments of chalk and flint are the most likely failures along these sites, although large scale failures are also possible.

The very low, low and medium risk sections are only rarely susceptible to major failure events because the future cliff line retreat was found to be negligible and no significant instability signs have been observed in the field. These sections consist of very steep cliffs composed of the Newhaven Chalk Formation which has demonstrated in the past due to the nature of the inclined conjugate fractures that it can retreat many meters in one failure event. However, due to the rarity of these events even the consequences are manageable, so it may be concluded that these sections will continue to need the attention of the local authority.

\section{Discussion}

Risk assessments of soft rocky cliffs are often based on historical recession records (Del Rio and Gracia, 2009). Marques (2008), who suggested a magnitude-frequency relationship in order to evaluate hazards along sea cliff environments, underlined that coastal studies in soft material cliffs are mainly directed to shoreline recession data because it is very rare to find systematic and detailed records of cliff failures. The widely applied approaches that are able to predict cliff recession ranging from those that are based upon statistical analysis of historical data, to those that are based on understanding and computing the physical process of shoreline change (Hall et al., 2002). A variety of techniques have also been developed that rely on the prediction of future coastlines in response to elements such as the rising sea level and the meteorological effects (rainfall, temperature) together with socioeconomic variables such as population density (Appeaning Addo et al., 2008; Brown et al., 2004; Leatherman, 1990 and Walkden et al., 2005; McLaughlin et al 2002). Although McLaughlin (2002) noted that the utilization of socioeconomic factors is of great importance to future coastal studies, he also indicated that the collection of such data presents many difficulties including the reliability of the sources and the complexity of the analysis. Other methodologies evaluate coastal failures considering a number of natural factors such as heavy rainfall events, tidal ranges and wave energy (Del Rio and Gracia, 2009; Duperret et al., 2004; Hutchinson, 1971). However, the collection and the analysis of large amounts of data for such methodologies produce complexity and require plenty of time, experience as well as exhaustive field work. A key advantage of this method is that the data required (e.g. historical maps, aerial photographs) is generally easy to obtain and requires only few days of site inspection. This converts the method into a practical approach which is affective, spatially and temporally accurate and easy to use.

Another positive aspect of the methodology presented is that the applied loss estimation system is applicable to all unstable, erodible coastlines that are composed by similar cliff 

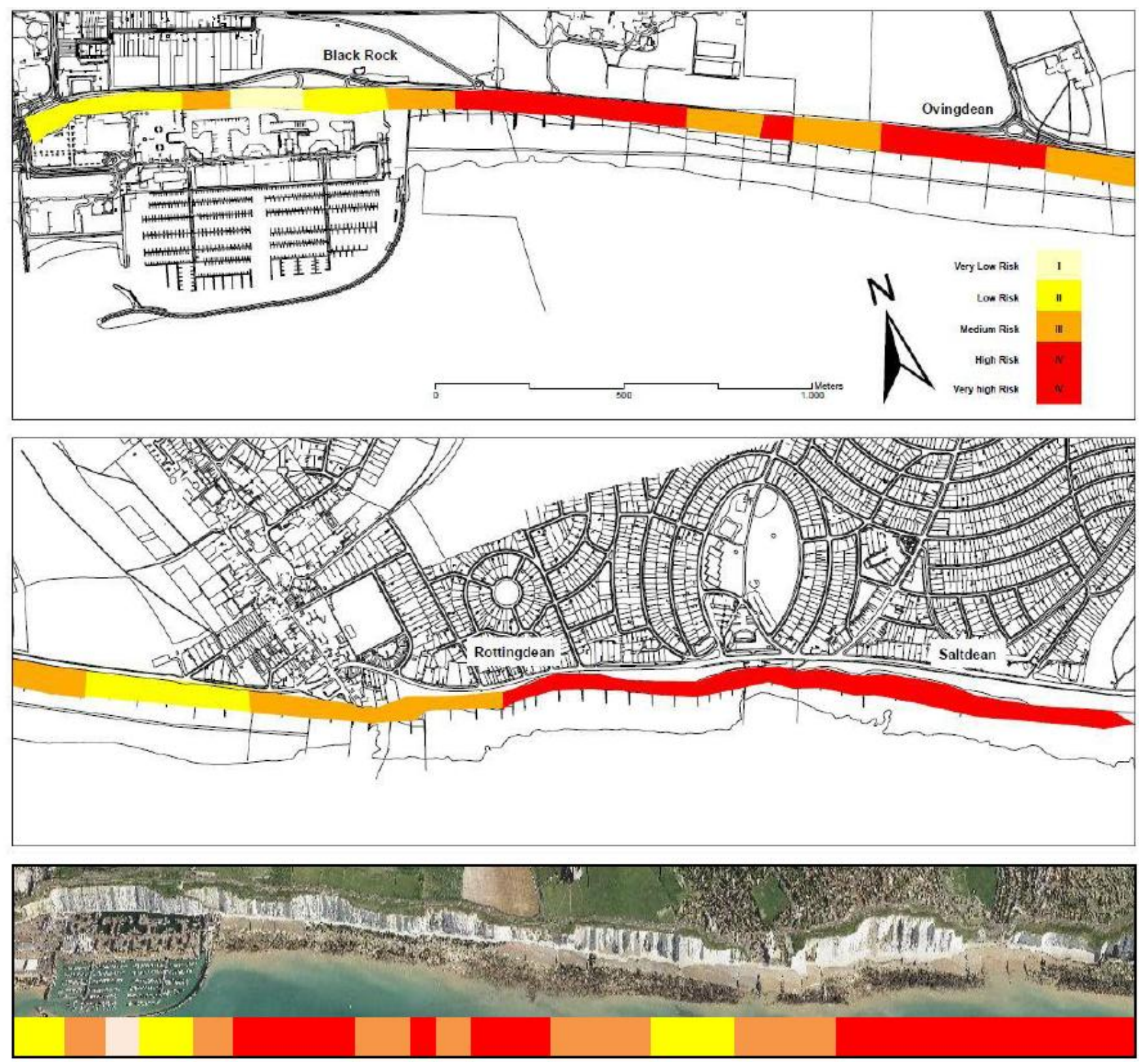

Fig. 10. The risk zonation plan of the site.

types or by cliffs with similar behavior. Hence, by adopting the described approach it should be possible to assess the risk of the cliff failure and the hazards associated with cliff retreat even at coastal environments with different recession rates. However, it should be noted that the shoreline retreat values presented in Table 4 were used for the area in question which means that other areas with different characteristics might need an alternative shoreline retreat value classification.

The fact that the present risk exposition assessment was undertaken taking into account future shoreline positions and geotechnical field observations in order to evaluate the risk of cliff failure contains some uncertainty. This uncertainty is attributed to the factors that control the future recession rates (e.g. future weather conditions), the judgment of the field engineer/geologist and the limitations of the methodologies used for predicting future shoreline position and assessing the condition of cliff failure. It is evident, that the reliability of the predicted shoreline positions is influenced by the accuracy of the calculated historical recession rates which in turn are dependent on the accuracy of coastal mapping. Historical coastal mapping is of questionable quality and leads to uncertainty because the shoreline mapping techniques applied in the past were affected by various factors such as the tidal ranges and the relative sea level changes. (Appeaning Addo et al., 2008). Hence, the validation of the applied technique is dependent on the level of confidence of the available 
data, (i.e. historical maps, aerial photographs). However, although we do not know the exact process of shoreline evolution, the predicted recession rates are useful to assess the cliff failures in terms of possible and different future scenarios (Barter et al., 2003; Lee and Clark, 2002). It should, also, be recognised that the use of Geographical Information Systems minimizes the errors of shoreline analysis and enhances the positional accuracy when digitizes coastlines from aerial photographs and historical maps (Nunes et al., 2009). Furthermore, the application of the DSAS ArcGis extension automates the calculations of historical recession rates and was proved to be a valuable tool that assisted the risk calculations' process.

Cliff recession is a phenomenon which is controlled not only by weather conditions but also by the physical properties and cliffs' rock mass character. Hence, it is argued that the present method could compromise the geotechnical factors that are related to cliff instability such as ground water conditions; shear strength of the material and other geotechnical data which can be used for an inventory stability analysis (Defra, 2002). A relevant work is demonstrated by Günther and Thiel (2008) for a fractured Cretaceous cliff section. The authors by applying a detailed kinematical rock slope failure analysis with structural fabric data and a slope stability model with the use of geotechnical parameters (i.e. material strength, hydraulic conductivity) they concluded to a combined susceptibility map of the site. Nevertheless, although the geotechnical monitoring can enhance the study with additional information, a sub-surface investigation, laboratory testing and detailed discontinuity survey could all have been applied so as to investigate the rock face stability in conjunction with the hazard mapping observations that have already been made. These are considered time consuming, expensive and demands experienced site investigation coastal engineers/earth scientists, which removes one of the key advantages to this method, its simplicity of use.

\section{Conclusions}

Hazards and the impact of climate change are felt more along coastal cliff environments. Due to the increasing numbers people who populate these zones the probability increases of negative consequences to the human and socio-economic infrastructure and the environment. This makes the ability to plan using this type of risk exposition assessment critical and therefore developing a strategic plan to mitigate the risks identified. This method identifies hazardous zones along coastal cliff environments and evaluates the risk exposition of vulnerable objects. Coastal instability has created a significant need for techniques that can evaluate the cliffs' condition and promote effective coastal management (Nunes et al., 2009).

The technique that was established for the needs of this study enables successful and realistic coastal risk exposition assessment along cliffed sections which can be applied by local authorities to help develop cliff management and contingent risk strategies. The outputs of the developed methodology can provide a valuable tool of better understanding the coastal hazards, taking into account geotechnical observations, historical erosion rates and human intervention at the coast allowing for the spatial and temporal relationships to be analysed.

The results of the applied methodology to the chalk cliffs between Brighton and Portobello show that approximately $50 \%$ of the cliff line under investigation is classed as high or very high level of risk in terms of the exposition of vulnerable objects. The areas identified at greatest risk were on the limbs of the cliff which rise out of the dry valleys regardless of coastal protection as a result of the combining hazards (frequent small single block failures from highly weathered sections of cliff) and the consequences (the high number of properties and coastal user along the valley sections).

The protected section has reduced the rate of shoreline recession rate compared to the unprotected section, but they have not eliminated it. Therefore the second section which received the high or very high risk was the unprotected zone as a result of high shoreline retreat values and again increased consequence score as a result of the close proximity of the coastal road to the cliff edge.

The present methodology displays an approach that with the contribution of likely socio-economic and environmental data as well as with the defence failure timeline could be utilized as a valid and easy to use cliff management policy tool.

Acknowledgements. The authors would like to thank Martin Eade of Brighton and Hove City Council for his support. The current work had financial support from The School of Earth and Environment, University of Leeds, UK.

Edited by: A. Günther

Reviewed by: two anonymous referees

\section{References}

Appeaning Addo, K., Walkden, M., and Mills, J. P.: Detection, measurement and prediction of shoreline recession in Accra, Ghana, ISPRS J. Photogramm. Remote Sens., 63, 543-558, 2008.

Barter, W. J., Burgess, A., Jay, H., and Hosking, S. D.: Future Coast: Predicting the Future Coastal Evolution of England and Wales, International Conference on Estuaries and Coasts, Hangzhou, China, 2003.

Baynes, F. J.: Sources of geotechnical risk, Q. J. Eng. Geol. Hydrogeol., 43, 321-331, 2010.

Bell, F. G.: Engineering Geology, 2nd Edn., Oxford, UK, 2007.

Benjamin, T., Gutierrez, S., Jeffress, W., and Robert E.: Basic Approaches for Shoreline Change and Land Loss Projections: Application to Fire Island, Coastal Sensitivity to Sea-Level Rise: A Focus on the Mid-Atlantic Region, USGS, 757, 761-763, New York, 2008. 
Boggett, A. D., Mapplebeck, N. J., and Cullen, R. J.: South Shore Cliffs, Whitehaven-Geomorphological survey and emergency cliff stabilization works. Q. J. Eng. Geol. Hydrogeol., The Geol. Soc. London, UK, 33, 213-226, 2000.

Bray, M. J. and Hooke, J. M.: Prediction of soft-cliff retreat with accelerating sea-level rise, J. Coast. Res., 13, 453-467, 1997.

Bristow, R., Mortimore, R. N., and Wood, J.: Lithostratigraphy for mapping the Chalk of southern England. Proc. Geol. Assoc., 108, 293-315, 1997.

British Geological Survey: Geology of the country around Brighton and Worthing, Memoir for 1:50 000 geological sheets 318 and 333 (England and Wales), London, 51-88, 1988.

Brown, I., Jude, S., Koukoulas, S., Nicholls, R., Dickson, M., Walkden, M., and Jones, A.: Dynamic Simulation and Visualisation of Coastal Erosion: Past, Present and Future, GISRUK04, University of East Anglia, Norwich, 2004.

Climate Change Impacts Review Group (CCIRG): Review of the potential effects of climate change in the United Kingdom, Department of the Environment, HMSO, London 199-209, 1996.

Crowell, M. and Leatherman, S. P.: Coastal erosion mapping and management, J. Coast. Res., 28, Coastal and Environmental Research Foundation, Royal Palm Beach Florida, 1-196, 1999.

Crowell, M., Douglas, B. C., and Leatherman, S. P.: On forecasting future U.S. shoreline positions: a test of algorithms, J. Coast. Res., 13, 1245-1255, 1997.

Defra: Soft Cliffs. Prediction of Recession Rates and Erosion Control Techniques, Soft Cliffs, Manual for Managers, Defra Flood Management Division, London, UK, 2002.

Del Rio, L. and Gracia, F. J.; Erosion risk assessment of active coastal cliffs in temperate environments, Geomorphology, 112, 82-95, 2009.

Dong, P. and Guzzetti, F.: Frequency-size statistics of coastal softcliff, J. Waterway, Port, Coastal Eng., 131, 37-42, 2005.

Dornbusch, U., Robinson, D., Moses, C., and Williams, R. B. G.: Chalk coast erosion and its contribution to the shingle budget in East Sussex, Z. Geomorphol., 144, 215-230, 2006.

Dornbusch, U., Moses, C. M., Robinson, D. A., and Williams, R. B. G.: Soft copy photogrammetry to measure shore platform erosion on decadal timescales, J. Coast. Conserv., 11, 193-200, 2008a.

Dornbusch, U., Robinson, D. A., Moses, C., and Williams, R. B. G.: Temporal and spatial variations of the chalk cliff retreat rate in East Sussex, 1873-2001, Mar. Geol., 249, 271-282, 2008b.

Duperret, A., Genter, A., Martinez, A., and Mortimore, R. N.: Coastal chalk cliff instability in NW France: role of lithology, fracture pattern and rainfall, in: Coastal Chalk Cliff instability, edited by: Mortimore, R. N. and Duperret, A. Geol. Soc., London, Eng. Geol., Special Publications, 20, 33-55, 2004.

Günther, A. and Thiel, C.: Combined rock slope stability and shallow landslide susceptibility assessment of the Jasmund cliff area (Rgen Island, Germany), Nat. Hazards Earth Syst. Sci., 9, 687698, doi:10.5194/nhess-9-687-2009, 2009.

Halcrow Group Limited, in association with Mark Lee and Terry Oakes Associates: Risk Assessment of Coastal Erosion Part One, Joint Defra/EA Flood and Coastal Erosion Risk Management R\&D Programme, R\&D Technical Report FD2324/TR1, 2007.

Hall, J. W., Meadowcroft, I. C., Lee, E. M., and Van Gelder, P. H. A. J. M.: Stochastic simulation of episodic soft coastal cliff recession, Coast. Eng., 46, 159-174, 2002.
Hearn, G. J. and Griffiths J. S.: Landslide hazard mapping, in: Landslide Surface Evaluation for Engineering Practice, edited by: Griffiths, J. S., Geol. Soc. London, Special publication, 18, 43-52, 2001.

High-Point Rendel: Cliff Management Risk Assessment - Brighton Marina to Saltdean, Volume 1 Text The report was prepared for Brighton and Hove City Council, Report No: R/H426/1/1, unpublished, 1999.

Himmelstoss, E. A.: "DSAS 4.0 Installation Instructions and User Guide" 2009, in: 2009, Digital Shoreline Analysis System (DSAS) version 4.0 - An ArcGIS extension for calculating shoreline change, edited by: Thieler, E. R., Himmelstoss, E. A., Zichichi, J. L., and Ergul, A., US Geological Survey Open-File Report, 2008.

Hook, J. M. and Kain, R. J. P.: Historical change in the physical environment: a guide to sources and techniques, Butterworth, 1982.

Hutchinson, J. N.: Field and Laboratory Studies of a fall in Upper Chalk cliffs at Joss Bay, Isle of Thanet, Roscoe Memorial Symposium, Cambridge University, 1971.

IPCC: IPCC Fourth Assessment Report: Climate Change 2007, Working Group I Report The Physical Science Basis, 2007.

Lakhan, V. C.: Coastal modelling and simulation, in: Encyclopedia of Coastal Science, edited by: Schwartz, M. L., Springer, The Netherlands, 266-269, 2005.

Lawrence, J. A., Mortimore, R. N., Eade, M. and Duperret, A.: Developing a strategy for coastal monitoring and management, in: 2007, Landslides and Climate Change - Challenges and Solutions, edited by: McInnes, R., Jakeways, J., Fairbank, H., and Mathie, E., Taylor \& Francis Group, 81-90, 2007.

Leatherman, S. P.: Modeling shore response to sea-level rise on sedimentary coasts, Prog. Phys. Geog., 14, 447-464, 1990.

Lee, E. M. and Clark, A. R.: Investigation and management of soft rock cliffs, Department for Environment, Food and Rural Affairs, London, 2002.

Marques, F. M. S. F.: Magnitude-frequency of sea cliff instabilities, Nat. Hazards Earth Syst. Sci., 8, 1161-1171, doi:10.5194/nhess8-1161-2008, 2008.

McLaughlin, S., McKenna J., and Cooper, J. A. G.: Socio-economic data in coastal vulnerability indices: constraints and opportunities, J. Coast. Res. SI, 36, 487-497, 2002.

Moore, R., Fish, P., Glennerster, M., and Bradbury, A.: Cliff behavior assessment: a quantitative approach using digital photogrammetry and GIS, Proc. 38th DEFRA Conf. of River and Coastal Engineers, 2003.

Mortimore, R. N.: The stratigraphy and sedimentation of the Turonian- Campanian in the southern Province of England, Zitteliana, 10, 515-529, 1983.

Mortimore, R. N.: Stratigraphy of the Upper Cretaceous White Chalk of Sussex, Proc. Geol. Assoc., 98, 97-139, 1986a.

Mortimore, R. N.: Controls on Upper Cretaceous sedimentation in the South Downs with particular reference to flint distribution, in: The Scientific Study of Flint and Chert, edited by: de Sieveking, G. and Hart, M. B., Cambridge University Press, Cambridge, 2142, 1986 b.

Mortimore, R. N. and Greensmith, J. T.: The Chalk of Sussex and Kent, Geol. Assoc., guide, 57, 1-193, 1997.

Mortimore, R. N., Wood, C. J., and Gallois, R. W.: British Upper Cretaceous Stratigraphy, GCR, 23, JNCC, Peterborough, 1-26, 
2001.

Mortimore, R. N., Lawrence, J., Pope, D., Duperret, A., and Genter, A.: Coastal cliff geohazard in weak rock: the UK Chalk cliffs of Sussex, in: Coastal Chalk Cliff stability, edited by: Mortimore, R. N. and Duperret, A., Eng. Geol. Special Publications, The Geol. Soc. London, UK, 3-31, 2004.

Mortimore, R. N., Lawrence, J. A., and Eade, M.: The INFORM Project (INformation FOr cliff Recession Management), Longterm monitoring programme for the cliffs between Black Rock and Saltdean, Annual Report 1, Brighton and Hove City Council Report, 2006.

Morton, R. A., Miller, T. L., and Moore, L. J.: National assessment of shoreline change part 1: Historical shoreline changes and associated coastal land loss along the US Gulf of Mexico, US Geological Survey Open File Report, 44, 2004-1043, 2004.

Nunes, M., Ferreira, O., Schaefer, M., Clifton, J., Baily, B., Moura, D., and Loureiro, C.: Hazard assessment in rock cliffs at Central Algarve (Portugal): A tool for coastal management, Ocean Coast. Manage., 52, 506-515, 2009.
Parry, S. and Ng, K. C.: The assessment of landslide risk from natural slopes in Hong Kong: an engineering geological perspective, Q. J. Eng. Geol. Hydrogeol., 43, 307-320, 2010.

Rawson, P. F., Allen, P., and Gale, A. S.: The Chalk Group - a revised lithostratigraphy, Geoscientist, 11 (1), 21, 2001.

Senfaute, G., Duperret, A., and Lawrence, J. A.: Micro-seismic precursory cracks prior to rock-fall on coastal chalk cliffs: a case study at Mesnil-Val, Normandie, NW France, Nat. Hazards Earth Syst. Sci., 9, 1625-1641, doi:10.5194/nhess-9-1625-2009, 2009.

UNDP: Reducing disaster risk: a challenge for development, United Nations Development Programme Bureau for Crisis Prevention and Recovery, New York, 161 pp., 2004.

Walkden, M. J. A. and Hall, J. W.: A predictive Mesoscale model of the erosion and profile development of soft rock shores, Coast. Eng., 52, 535-563, 2005. 